\title{
RELATIONS BETWEEN PARTIES TO A DISPUTE AND ITLOS
}

\begin{abstract}
ITLOS case study shows that it strongly contributed to the development of the international law of the sea. Author considers such cases that allowed ITLOS to contribute to the provisions regarding preservation and protection of the marine environment, delimitation of the maritime boundary and responsibilities of the States. The author affirms that Tribunal contributed to progressive development of the law of the See. In its practical activity ITLOS has already made much for the development of the international law of the sea, especially in determination of those institutes and concepts, which were not clearly enough provided for in the Convention. The most demonstrative in this respect is the realization of the competence of prompt release of vessels which is quite new for judicial procedure. In realizing this competence ITLOS had to interpret and concretize many articles of the Convention, especially as to the grounds for detention of foreign vessels in the EEZ and other areas of national jurisdiction; cleared up such an important rule of national law as the amount of financial security for a release of a ship: the rule is borne by international law and being common for many national systems became actually a general principle of law. Keywords: ITLOS, process verbal, acquiescence, marine environment, delimitation, responsibilities, Convention, Contribution, provisions regarding preservation, protection.
\end{abstract}

\section{Contribution to the provisions regarding preservation and protection of the marine environment}

\section{(}

rovisions regarding preservation and protection of the marine environment were touched upon by ITLOS in the course of deliberations in connection with requests to prescribe provisional measures under article 290 of UNCLOS. The Tribunal may be requested to prescribe provisional measures in two situations:

- first where a dispute on the merits has been submitted to the Tribunal;

- second when a dispute on the merits has been submitted to an arbitral tribunal, pending its constitution.

According to article 290 paragraph 5 of UNCLOS when a party to a dispute submitted to an arbitral tribunal request provisional measures, the tribunal has the power to grant such measures pending the constitution of arbitral tribunal, unless the parties have agreed to seize another court or tribunal within two weeks of the date of the request for provisional measures. Thus, the Tribunal may at the request of a State party, prescribe provisional measures against another State Party pending the final decision to be given not by the Tribunal itself, but an arbitral tribunal that is yet to be constituted. Hence an important provision is, that the Tribunal must consider that prima facie, the arbitral tribunal to be constituted would have jurisdiction.

It is notable that provisional measures that is measures with the aim to amend an urgent situation in the practice of ITLOS in most cases were connected with environmental problems. The tribunal may prescribe provisional measures not only to preserve the respective rights of the parties to the dispute, but also «to prevent serious harm to marine environment» ${ }^{1}$.

\section{a) Southern Bluefin Tuna Case}

In 1999 the Commonwealth of Australia and New Zealand sought provisional measures against an increase in Japanese tuna fishing in the Southern Ocean.

Southern bluefin tuna is listed in Annex I UNCLOS as a highly migratory species. In 1993 Australia, New Zealandand Japan adopted the Convention for the conservation of Southern bluefin tuna. Under the 1993 Convention the Commission for the Conservation of Southern Bluefin Tuna would determine a total allowable catch and allocate national quotas by unanimous decision.

Australia and New Zealand sought an order from ITLOS suspending the experimental fishing programme pending a hearing on the merits, arguing that the fishing by Japan was for commercial purposes, with minimal scientific benefit, and would further endanger a severely depleted stock. The applicants alleged that Japan had violated their rights under Arts 64, and 116 to 119 UN Convention on the Law of the Sea and that further catches of southern bluefin tuna would cause immediate harm to those rights. ITLOS

\footnotetext{
${ }^{1}$ Art.290 (1).
} 
noted 'that there is no disagreement between the parties that the stock of southern bluefin tuna is severely depleted and is at its historically lowest levels and that this is a cause for serious biological concern'2. It concluded that therefore the parties should 'act with prudence and caution to ensure that effective conservation measures are taken to prevent serious harm to the stock of southern bluefin tuna' ${ }^{3}$ For those reasons, ITLOS found that provisional measures were necessary 'as a matter of urgency' pending constitution of an arbitral tribunal.

According to many authors ITLOS developed some principles on the protection and preservation of the marine environment ${ }^{4}$. Although there is no express reference in the Order to the precautionary principle itself, the Tribunal nevertheless prescribed de facto precautionary measures and seems at least implicitly to have relied on that principle. As Alan Boyle submits, Bluefin Tuna Case shows that a precautionary approach does not reverse the burden of proof of harm in fisheries cases, even if the position with regard to dumping, or trade in hazardous waste is to ban such activities unless they can be shown to pose no risk of harm ${ }^{5}$.

\section{b)Mox Plant Cases}

The Mox Plant cases ${ }^{6}$ refer to a dispute between Ireland and the UK about the authorization of a MOX (Mixed Oxide Fuel) Plant in the North-West of England on the coast of Irish Sea, whose operations including transportation of radioactive material to and from the plant, would, according to Ireland, pollute the Irish Sea. Pending the constitution of an arbitral tribunal under article 287 and Annex VII of the UNCLOS, Ireland asked ITLOS to prescribe provisional measures under article 290 paragraph 5, mainly - sus-

\footnotetext{
${ }^{2}$ Southern Bluefin Tuna Case (Australia and New Zealand v Japan). (Award on Jurisdiction and Admissibility). 4 August 2000.) para. 71

${ }^{3}$ Bluefin Tuna Case para. 77

${ }^{4}$ Gwenaele Rashbrooke, The International Tribunal for the Law of the Sea - a forum for the Development of Principles of International Environmental Law, 19 Int'1 J. Marine and Coastal Law, \# 4, 523 (2004) at 532.

5 Alan Boyle, Southern Bluefin Tuna Cases, in: on-line Encyclopedia of public international law. www.mpepil.org

${ }^{6}$ The MOX Plant Case (Ireland v United Kingdom) (Provisional Measures) ITLOS Case No 10 (3 December 2001) <http://itlos. mcs-world.de/cgi-bin/cases/case_detail.pl?id=10\&lang=en>
}

pension of the authorization of the plant and the cessation of marine transport of radioactive substances in connection with its operation. ${ }^{7}$ Ireland insisted on receiving the full information about the plant.

Both countries were ready to turn to arbitration provided by the Convention for the Protection of the Marine Environment of the North-East Atlantic (OSPAR $)^{8}$. Pending the decision of the arbitration tribunal Ireland requested ITLOS to prescribe provisional measures.

In its order ITLOS declared the duty to cooperate to be the fundamental principle in the prevention of pollution of marine environment under UNCLOS and general international law. ${ }^{9}$ On the other hand, ITLOS found that there was no urgency requiring the measures requested by Ireland. It was based on the fact that Ireland had not produced sufficient evidence of environmental harm in relation to the time period before constitution of an arbitral tribunal. ${ }^{10}$ ITLOS nevertheless prescribed a different provisional measure, consisting in improved cooperation and the provision of information; R.Chirchill doubts the appropriateness of the measures since he thinks them not to be a response to the urgency of the situation ${ }^{11}$.

\section{c)Case concerning Land Reclamation by Singapore}

In the Case concerning Land Reclamation by Singapore in and around the straitsof Johor"12 provisional measures were sought by Malaysia in relation to land reclamation works being carried out by Singapore in and around the Straits of Johor which separates the island of Singapore from Malaysia which allegedly impinge upon Malaysia's rights.

Malaysia claimed that Singapore's land reclamation projects were in breach of its duties under inter-

\footnotetext{
${ }^{7}$ See Haritini Dipla, op.cit, p.247.

${ }^{8}$ Convention for the Protection of the Marine Environment of the North-East Atlantic (opened for signature 22 September 1992, entered into force 25 March 1998) (1993) 32 ILM 1069.

${ }^{9}$ The MOX Plant Case (Ireland v United Kingdom) (Provisional Measures) ITLOS Case No 10. Order of 3 December 1999, para 31(3)

${ }^{10}$ See Gwenaele Rashbrooke, op.cit, p. 530

${ }^{11}$ Robin Chirchill, MOX Plant Arbitration and Cases , in: www. mpepil.org, p. 21.

${ }^{12}$ Case concerning Land Reclamation by Singapore in and around the straits of Johor (Malaysia v Singapore). Request for provisional measures. Order of 8 October, 2003.
} 
national law, including the duties to preserve and protect marine environment and its procedural duties of cooperation, notification and exchange of information under the UNLOS. ${ }^{13}$ Malaysia also insisted on the application of the good faith obligation in Article 300 and the precautionary principle, which «must direct any State party in the application and implementation of those obligations». ${ }^{14}$

Finally, the ITLOS unanimously prescribed a provisional measure under article 290 paragraph 5 of UNCLOS, consisting in the duty to cooperate and enter into consultations in order to establish a mechanism for exchanging information and on assessing the risks or effects of land reclamation on the marine environment. ${ }^{15}$

However the measures do not require Singapore to suspend land reclamation works. Following the Order of the Tribunal, the two States established a Group of Independent experts (GOE), which conducted a study on the reclamation activities and recommended, as required by the Order of the Tribunal, measures to deal with any adverse effects. ${ }^{16}$ As a result this procedure enabled the two States to exchange views and information in such a way as to agree ad referendum on the text of a draft Settlement Agreement.

In the doctrine a point of view prevailes that this decision is disappointing in terms of its development of legal principles. ${ }^{17}$ In fact it follows the MOX case in affirming the importance of the cooperation principle, and repetas the «prudence and caution» wording as the basis for the measures prescribed. However no clarification is provided as to whether there is any link to the precautionary principle.

What we can observe from the ITLOS decisions in Bluefin Tuna Case and Land Reclamation by Singapore in and around the Straits of Johor is that provisional measures applications may afford a useful method for tackling failure to do an environmental impact assessment. In both cases ITLOS found that the risk of harm to the marine environment could not be excluded. In Land Reclamation it expressly ordered the parties

\footnotetext{
${ }^{13}$ Malaysia relied on Art. 2, 15, 123, 192, 194, 198, 200, 204, 205, 206, 210, 300 of UNCLOS.

${ }^{14}$ Para 18 of Malaysia's request for Provisional measures dated 4 September 2003

${ }^{15}$ Order of 8 October 2003, para 96 and 99

${ }^{16}$ See Haritini Dipla, op cit.,p.248

${ }^{17}$ See Gwenaele Rashbrooke, op.cit.,p. 532
}

to assess the risks and effects of the works, while in Bluefin Tuna Case the effect of its order was that catch quotas could only be increased by agreement after further studies of the state of the stock.

\section{Delimitation}

\section{a)Maritime boundary between Bangladesh and Myanmar}

Dispute concerning delimitation of the maritime boundary between Bangladesh and Myanmar in the Bay of Bengal ${ }^{18}$ concerns the delimitationof the maritime boundary in the Bay of Bengal with respect to the territorial sea, the exclusive economic zone and the continental shelf. It was the first case of the Tribunal relation to the delimitation of maritime boundaries. More that that, the judgment touched upon the problems of delimitation of continental shelf beyond $200 \mathrm{~nm}$. The judgement was delivered on 14 March 2012.

Speaking generally, the case shows a step by step development of the international law of delimitation. The Tribunal followed the methods of achieving an equitable result used by the ICJ and arbitration tribunals. ITLOS paid much attention and elaborated the notions of delimitation of the territorial sea, the exclusive economic zone and the continental shelf, respectively; equidistance principle; special circumstance; historic title; the single maritime boundary.

As Judge T.Treves rightly declared in his declaration, "with the present judgment the Tribunal becomes an active participant in this collective interpretative endeavor [of the Convention]. While it has adopted the methodology developed by the International Court of Justice and recent arbitral awards, the Tribunal has also contributed its own grain of wisdom and particular outlook" 19 .

What is important, in my view, is the qualification of the "agreed minutes" of 1974, signed by the heads of delegation of the states. The Tri-

\footnotetext{
${ }^{18}$ Dispute concerning delimitation of the maritime boundary between Bangladesh and Myanmar in the Bay of Bengal (Bangladesh v. Myanmar). Judgment of 14 March 2012.

${ }^{19}$ Dispute concerning delimitation of the maritime boundary between Bangladesh and Myanmar in the Bay of Bengal. Declaration by Judge T.Treves, p.2.
} 
bunal held that the Agreed Minutes were no more than a record of a conditional understanding ande were not intended to create legal obligations: the head of the Myanmar delegation did not have the authority to engage his State; and the Agreed Minutes had not been submitted to the procedure required by their respective constitutions for binding international agreements ${ }^{20}$.

\section{b)The Continental shelf boundary beyond 200 miles}

This part of the judgment of ITLOS in the Dispute concerning delimitation of the maritime boundary between Bangladesh and Myanmar in the Bay of Bengal might be the most interesting and important due to the novelty of the subject. Many issues not fully clear by themselves have interwoven into a new puzzle: the concept of the common heritage of mankind; the competences of the UN Comission on the limits of continental shelf (CLCS); the right of a judicial body to delimit overlapping areas beyond 200nm; relationship between the institutions established by the Convention; and others.

The core of the issue is that UNCLOS provides that a state's continental shelf may extend beyond 200 miles if certain geological and geomorphological criteria set out in Article 76 are fulfilled. A state that considers that its continental shelf extends beyond 200 miles must make a submission setting out its view as to the outer limit of its shelf to the Commission on the Limits of the Continental Shelf (CLCS), a body of independent experts in geology, geophysics and hydrography established by UNCLOS. The CLCS is to make recommendations to the coastal state regarding its submission. The outer limit of the shelf established on the basis of those recommendations is final and binding ${ }^{21}$. The very idea of submitting the delimitation in the Bay of Bengal to judicial settlement might have been based on the sheer necessity: both Bangladesh and Myanmar have made submissions to the CLCS to approve their right to the outer continental shelf, whereas the Rules of Procedure of the CLCS provide that the CLCS shall not consider submissions relating

\footnotetext{
${ }^{20}$ Judgment, paras. 92-8.

${ }^{21}$ Robin Chirchill, The Bangladesh/Myanmar Case: Continuity and Novelty in the Law of Maritime Boundary Delimitation, Cambridge Journal of International and Comparative Law, 2012, \#1, p. 150
}

to an area where there is a dispute unless both/all parties to such a dispute give their consent ${ }^{22}$.

The most important, in my view, is ITLOS's conclusion that any delimitation is subject to general international law: "the delimitation method to be employed in the present case for the continental shelf beyond 200 nautical miles should not differ from that within $200 \mathrm{~nm}$. Accordingly, the equidistance/ relevant circumstances method continues to apply for the delimitation of the continental shelf beyond $200 \mathrm{~nm} .{ }^{.23}$ ITLOS decided that the boundary between the parties' overlapping continental shelves beyond $200 \mathrm{~nm}$ should be a continuation of the single maritime boundary line until it reached the area where the rights of third States (i.e. India) might be affected. ${ }^{24}$

\section{Responsibilities of states in the Area}

1 February 2011 the Seabed Disputes Chamber unanimously adopted the Advisory Opinion on the "Responsibilities and Obligations of States Sponsoring Persons and Entities with respect to Activities in the Area." ${ }^{25}$ The Chamber was to answer three questions, mainly concerning the responsibility and liability of a state for an entity it has sponsored.

The opinion is of historical importance because one can say, it marks the beginning of filling the concept of the common heritage of mankind with a real legal contents. The matter is, the UNCLOS declared the deep seabed beyond the jurisdiction of states "the common heritage of mankind" without any further specifications $^{26}$.

Exploration and exploitation of minerals in the Area are governed by the International Seabed Authority ("ISA"). All prospective exploration and exploitation activities are required to be sponsored by

\footnotetext{
22 Para. 5(a), Ann. I, Rules of Procedure, CLCS available at $<$ http://daccess-dds-ny.un.org/doc/UNDOC/GEN/N08/309/23/ PDF/N0830923.pdf?OpenElement (last visited 2 February 2013)

${ }^{23}$ Judgment, para. 455.

${ }^{24}$ Para 462 of the Judgement

${ }^{25}$ International Tribunal for the Law of the Sea. Seabed Disputes Chamber. Advisory Opinion "Responsibilities and Obligations of States Sponsoring Persons and Entities With Respect To Activities in the Area". 1 February 2011.

${ }^{26}$ United Nations Convention on the Law of the Sea art. 137, opened for signature Dec. 10, 1982, 1833 U.N.T.S. 396, available at http://www.un.org/Depts/los/convention_agreements/texts/ unclos/unclos_e.pdf
} 
a State Party to the 1982 Convention. In applying for an exploration or exploitation license, an entity submits two broadly similar areas for consideration. If a license is granted, the ISA determines which area will be allotted to the applicant; the second area is reserved for activities by the ISA through the Enterprise or "in association with developing states." 27

In April 2008, Nauru and Tonga-two small Pacific Island developing states-each put forward a proposal for activities in reserved areas. Each of these states was sponsoring a commercial entity to undertake these activities. There were some doubts that such small states, and categorized as developing state, that they would be able to bear responsibilities and liabilities for the possoble breaches and omissions made by the entities busy with the activities in the deep seabed mining.

The Chamber first determined the phrase "activities in the Area"; then itemized the constituent elements of the obligation "to ensure" and found it analogous to the obligation of due diligence and conduct that the International Court of Justice found in the recent Pulp Mills Case; on the wider and controversial question of the treatment of developing states, the Chamber unequivocally endorsed the principle of equality. The Chamber ruled that if damage occurred, and the sponsoring state had failed to take "all necessary and appropriate measures to ensure compliance" by its contractor, then the state would be liable. Laws, regulations, and administrative measures must be in force at all times that the contract with the Authority is in force.

\section{CONCLUSION}

The contribution of the Tribunal into progressive development of the law of the see can be traced and measured along the same lines as it is with other international judicial bodies. But there are also some important peculiarities born by special characteristics of the law of the sea.

The time passed has shown some consistency in the manner of interpretation used by the Tribunal. What is clear about its manner of interpretation is that it is guided by the ICJ's experience and opinion, that treaties must be interpreted and applied in the framework of a legal system as a whole prevailing at the moment of interpretation,

In its practical activity ITLOS has already made much for the development of the international law of the sea, especially in determination of those institutes and concepts which were not clearly enough provided for in the Convention.

The most demonstrative in this respect is the realization of the competence of prompt release of vessels which is quite new for judicial procedure. In realizing this competence ITLOS had to interpret and concretize many articles of the Convention, especially as to the grounds for detention of foreign vessels in the EEZ and other areas of national jurisdiction; cleared up such an important rule of national law as the amount of financial security for a release of a ship: the rule is borne by international law and being common for many national systems became actually a general principle of law.

Amounting to a general principle of law is the rule of genuine link between a ship and the flag state, although it is in the process of crystallization.

An important phenomenon is the development of the institute of provisional measures. Although ITLOS works in this respect, as in many others, in close contact with the disputing parties, one can see a rather large space of freedom of discretion appropriated by ITLOS.

\section{Библиография:}

1. Robin Chirchill, The Bangladesh/Myanmar Case: Continuity and Novelty in the Law of Maritime Boundary Delimitation, Cambridge Journal of International and Comparative Law, 2012, \#1, p.150

\footnotetext{
${ }^{27}$ David Freestone, Advisory Opinion of the Seabed Disputes Chamber of International Tribunal for the Law of the Sea on "Responsibilities and Obligations of States Sponsoring Persons and Entities With Respect To Activities in the Area". March 9. 2011. Volume 15. Issue 7. ASIL Insight http://www. asil.org/ insights110309.cfm.
} 
2. Gwenaele Rashbrooke, The International Tribunal for the Law of the Sea - a forum for the Development of Principles of International Environmental Law, 19 Int'1 J. Marine and Coastal Law, \# 4, 523 (2004) at 532.

3. А. А. Тодоров. Территориальный элемент состава пиратства по уголовному законодательству России и зарубежных стран // Право и политика. - 2012. - № 10. - С. 104-107.

4. М. Р. Хубиева. Конкуренция юрисдикций в случае предписания временных мер правовой защиты при разрешении международных морских споров // Международное право и международные организации / International Law and International Organizations. - 2012. - № 2. - C. 104-107.

5. А. С. Касаткина. Правовые основы регулирования международных пассажирских перевозок // Право и политика. - 2012. - № 3. - С. 104-107.

6. Г. Ц. Ли. Морская политика Китая в регионе АТР // Национальная безопасность / nota bene. - 2012. - № 1. - С. 104-107.

7. С. Н. Овчинников. Пограничный контроль морских судов в Российской Федерации: законодательство и практика // Право и политика. - 2011. - № 12. - С. 104-107.

8. М. М. Каленченко. Территориальная охрана морской среды и свобода судоходства. // Международное право и международные организации / International Law and International Organizations. - 2010. - № 2 .

9. Ли Гуань цюнь. Китайская морская стратегия и политика на современном этапе // Политика и Общество. - 2011. - № 6. - С. 104-107.

10. В. Н. Конышев, А. А. Сергунин. Ремилитаризация Арктики и безопасность России // Национальная безопасность / nota bene. - 2011. - № 3. - С. 104-107.

11. Е. Б. Ганюшкина. Международный орган по морскому дну, Комиссия по границам континентального шельфа, Международный трибунал по морскому праву и некоторые другие международные объединения,связанные с Конвенцией ООН по морскому праву 1982 г. // Международное право и международные организации / International Law and International Organizations. - 2010. - № 4.

12. А.М. Ибрагимов. Специфика норм о гарантиях в международном морском и речном праве // Право и политика. - 2009. - № 9.

13. Ерпылева Н.Ю. Международный коммерческий арбитраж: правовые основы функционирования // NB: Международное право. - 2013. - № 1. - C.1-74. DOI: 10.7256/2306-9899.2013.1.545. URL: http://e-notabene.ru/wl/article_545.html

14. Каламкарян Р.А. Роль Международного Суда ООН в деле поддержания международного правопорядка // NB: Международное право. - 2013. - № 1. - C.184-214. DOI: 10.7256/2306-9899.2013.1.690. URL: http://e-notabene.ru/wl/article_690.html

15. Каламкарян Р.А. Включенность Российской Федерации в деятельность Международного Суда $\mathrm{OOH}$ в деле обеспечения международной законности и правопорядка // NB: Международное право. - 2013. - № 2. - C.85-118. DOI: 10.7256/2306-9899.2013.2.691. URL: http://e-notabene.ru/wl/article_691.html

16. Кузьмина Ю.А. Некоторые особенности практики Европейского Суда в отношении Российской Федерации // NB: Международное право. - 2013. - № 3. - C.68-87. DOI: 10.7256/2306-9899.2013.3.2424. URL: http://e-notabene.ru/wl/article_2424.html

\section{References (transliteration):}

1. Robin Chirchill, The Bangladesh/Myanmar Case: Continuity and Novelty in the Law of Maritime Boundary Delimitation, Cambridge Journal of International and Comparative Law, 2012, \#1, p.150

2. Gwenaele Rashbrooke, The International Tribunal for the Law of the Sea - a forum for the Development of Principles of International Environmental Law, 19 Int'1 J. Marine and Coastal Law, \# 4, 523 (2004) at 532.

3. A. A. Todorov. Territorial'nyi element sostava piratstva po ugolovnomu zakonodatel'stvu Rossii i zarubezhnykh stran // Pravo i politika. - 2012. - № 10. - S. 104-107. 
DOI: $10.7256 / 2226-6305.2014 .2 .11623$

При цитировании этой статьи сноска на dоі обязательна

Международные судебные органы / International judicial bodies

4. M. R. Khubieva. Konkurentsiya yurisdiktsii v sluchae predpisaniya vremennykh mer pravovoi zashchity pri razreshenii mezhdunarodnykh morskikh sporov // Mezhdunarodnoe pravo i mezhdunarodnye organizatsii / International Law and International Organizations. - 2012. - № 2. - S. 104-107.

5. A. S. Kasatkina. Pravovye osnovy regulirovaniya mezhdunarodnykh passazhirskikh perevozok // Pravo i politika. - 2012. - № 3. - S. 104-107.

6. G. Ts. Li. Morskaya politika Kitaya v regione ATR // Natsional'naya bezopasnost' / nota bene. - 2012. - № 1. - S. 104-107.

7. S. N. Ovchinnikov. Pogranichnyi kontrol' morskikh sudov v Rossiiskoi Federatsii: zakonodatel'stvo i praktika // Pravo i politika. - 2011. - № 12. - S. 104-107.

8. M. M. Kalenchenko. Territorial'naya okhrana morskoi sredy i svoboda sudokhodstva. // Mezhdunarodnoe pravo i mezhdunarodnye organizatsii / International Law and International Organizations. - 2010. - № 2.

9. Li Guan' tsyun'. Kitaiskaya morskaya strategiya i politika na sovremennom etape // Politika i Obshchestvo. - 2011. - № 6. - S. 104-107.

10. V. N. Konyshev, A. A. Sergunin. Remilitarizatsiya Arktiki i bezopasnost' Rossii // Natsional'naya bezopasnost' / nota bene. - 2011. - № 3. - S. 104-107.

11. E. B. Ganyushkina. Mezhdunarodnyi organ po morskomu dnu, Komissiya po granitsam kontinental'nogo shel'fa, Mezhdunarodnyi tribunal po morskomu pravu i nekotorye drugie mezhdunarodnye ob' edineniya,svyazannye s Konventsiei OON po morskomu pravu 1982 g. // Mezhdunarodnoe pravo i mezhdunarodnye organizatsii / International Law and International Organizations. - 2010. - № 4.

12. A.M. Ibragimov. Spetsifika norm o garantiyakh v mezhdunarodnom morskom i rechnom prave // Pravo i politika. - 2009. - № 9.

13. Erpyleva N.Yu. Mezhdunarodnyi kommercheskii arbitrazh: pravovye osnovy funktsionirovaniya // NB: Mezhdunarodnoe pravo. - 2013. - № 1. - S.1-74. DOI: 10.7256/2306-9899.2013.1.545. URL: http://e-notabene.ru/wl/article $545 . \mathrm{html}$

14. Kalamkaryan R.A. Rol' Mezhdunarodnogo Suda OON v dele podderzhaniya mezhdunarodnogo pravoporyadka // NB: Mezhdunarodnoe pravo. - 2013. - № 1. - S.184-214. DOI: 10.7256/2306-9899.2013.1.690. URL: http://e-notabene.ru/wl/article_690.html

15. Kalamkaryan R.A. Vklyuchennost' Rossiiskoi Federatsii v deyatel'nost' Mezhdunarodnogo Suda OON v dele obespecheniya mezhdunarodnoi zakonnosti i pravoporyadka // NB: Mezhdunarodnoe pravo. - 2013. - № 2. - S.85-118. DOI: 10.7256/2306-9899.2013.2.691. URL: http://e-notabene.ru/wl/article_691.html

16. Kuz'mina Yu.A. Nekotorye osobennosti praktiki Evropeiskogo Suda v otnoshenii Rossiiskoi Federatsii // NB: Mezhdunarodnoe pravo. - 2013. - № 3. - S.68-87. DOI: 10.7256/2306-9899.2013.3.2424. URL: http://e-notabene.ru/wl/article_2424.html 